The last section on "General observations" is unique. It consists of about 30 pages of advice to students and investigators. It is well written, interesting, and stimulating. It is to be regretted that it should have been published where it will necessarily have relatively so small a circle of readers. The ideas running through the section may be indicated by some of the headings, as "On subsidiary studies," "On beginning work thoughtlessly," "On repetition of experiments, other people's, one's own," "On publication," "On keeping one's own counsel," "On sharing credits," and "On attending meetings and keeping up membership in societies, and on being generally public spirited and helpful in science." An excellent index is provided.-R. E. Buchanan.

\title{
Geography of plants
}

In a compact volume, HARDY ${ }^{2}$ has given a comprehensive review of the vegetation of the world in very readable form. Maps of such climatic factors as rainfall and temperature, as well as of the vegetation itself, are upon a small scale, but seem very accurate, although necessarily lacking in detail and expressing a much greater rigidity than obtains in nature. The general characterization of the vegetation is fairly accurate, although one is often at a loss to know just what genera and species are intended on account of the rather complete absence of scientific names. The few scientific terms employed are so lacking in accuracy as to shake one's confidence in the facts presented with which he is not already familar. Irregularities in spelling and capitalization might be overlooked, but to designate the long-leaved pine on the Atlantic slope as Pinus Lambertiana, or to refer any of the North American "cedars" to the genus Cedrus is certainly unpardonable. Such inaccuracies in terminology, together with an entire absence of citations of the sources of data, will prevent the book being used by advanced classes, although it will probably be found useful for imparting general impressions and in sketching in broad outline the vegetation of the various continents.-GEO. D. FULLER.

\section{MINOR NOTICES}

Practical botany.-MARTIN's textbook entitled Botany for Agricultural Students has appeared in a second edition and with a new title. ${ }^{3}$ The general purpose of the text was stated in a previous review. 4 In the new edition portions of the text have been re-written, to correct errors and to increase clearness, but the chief changes occur in the treatment of heredity and evolution, a chapter on variation being added. The matter is well presented, clear in style and organization, and is certainly well adapted to its constituency.J. M. C.

${ }^{2}$ Hardy, M. E., The geography of plants. I2mo. pp. xix +327 . figs. 115 . Oxford: Clarendon Press. I920.

3 Martin, J. N., Botany with agricultural applications. 8vo. pp. xii+604. figs. 49o. New York: Wiley \& Sons. I920.

4 Bот. Gaz. 68:308. I919. 


\section{$2 \mathrm{BHL}$ Biodiversity Heritage Library}

1921. "Practical Botany." Botanical gazette 71(5), 402-402.

https://doi.org/10.1086/332855.

View This Item Online: https://www.biodiversitylibrary.org/item/109572

DOI: https://doi.org/10.1086/332855

Permalink: https://www.biodiversitylibrary.org/partpdf/224224

\section{Holding Institution}

Missouri Botanical Garden, Peter H. Raven Library

\section{Sponsored by}

Missouri Botanical Garden

\section{Copyright \& Reuse}

Copyright Status: Public domain. The BHL considers that this work is no longer under copyright protection.

This document was created from content at the Biodiversity Heritage Library, the world's largest open access digital library for biodiversity literature and archives. Visit BHL at https://www.biodiversitylibrary.org. 